\title{
CHARACTERISTICS OF EMERGENCY PUBLIC PROCUREMENT CARRIED OUT IN ROMANIA AS A RESULT OF THE COVID-19 CRISIS
}

\author{
Ionel PREDA ${ }^{a *}$, Cezar-Petre SIMION ${ }^{b}$ \\ ${ }^{a, b}$ Bucharest University of Economic Studies, Romania
}

DOI: $10.24818 / \mathrm{IMC} / 2020 / 03.14$

\begin{abstract}
The COVID-19 virus appeared in December 2019 in China and spread rapidly around the world becoming a pandemic. One of the measures to combat the pandemic that has been implemented in all affected states was emergency public procurement.The article presents the literature on emergency public procurement and analyzes the most important characteristics of emergency public procurement carried out in Romania to combat the COVID-19 pandemic: evolution, deficiencies, problems encountered, advantages, disadvantages, risks and vulnerabilities.The article also describes the level of readiness of the Romanian public authorities and the differences between the emergency public procurement carried out to combat the COVID-19 pandemic and other emergency procurement.
\end{abstract}

KEYWORDS: corruption, Covid-19, emergency public procurement, prices, risks.

\section{INTRODUCTION}

In December 2019, a new type of coronavirus outbreak occurred in the city of Wuhan in China, and then spread very rapidly to most regions of China and most countries. The spread of the virus also reached the European continent, so that in January 2020 the first cases appeared in some EU Member States. In February 2020, a significant increase in COVID-19 cases took place in northern Italy (European Council, 2020). The first Romanian citizen was diagnosed with COVID-19 on 26.02.2020. He has come into contact with an Italian citizen who has visited Romania, had no symptoms and thought he had a mere cold which is commonly treated. He was admitted to hospital in quarantine conditions and on 01.03.2020 he was discharged because all tests carried out showed that he was cured (Alecsandru, 2020). The epidemic continued to spread in Romania, so that on 16.06.2020 there were registered 1,437 deaths, 22,415 cases of persons infected with COVID-19 and 16,071 cured persons (Health Minister of Romania, 2020). Figure 1 shows the evolution in Romania of the daily number of illnesses and deaths caused by the COVID-19 virus.

The inadequate training of medical personnel, the lack / failure to comply with the working procedures in the medical field and especially the lack / inadequacy of the medical protection materials have led to two consequences that have aggravated the crisis management in Romania: the illness of a large number of medical personnel with COVID - 19 and the resignation of other health professionals. For example, in Romania on 16.04.2020, out of the total of 7,702 persons infected with COVID-19, 981 were health professionals, meaning a percentage of $12.7 \%$.An emergency response requires the procurement and delivery of a wide range of products and services: medicines, sanitary materials, medical equipment, food, drinking water, electricity, sewage, transportation, non-food items and housing (Schultz \& Soreide, 2008). But many needs that arise in emergency situations (such as the COVID-19 crisis) cannot be anticipated and rapid

*Corresponding author. E-mail address: predaionel4@gmail.com 
procurement is needed. This research analyzes the characteristics of public procurement that needs to be carried out as a matter of urgency in order to meet the urgent needs of the affected population.

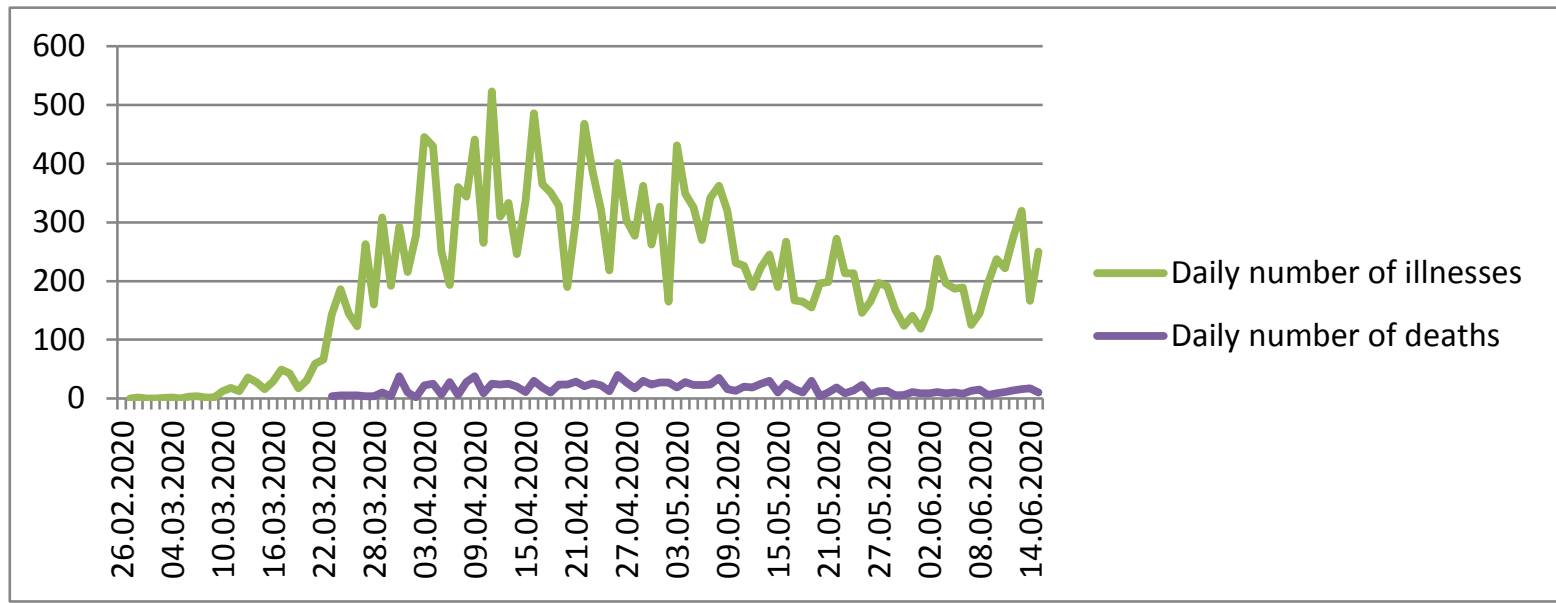

Figure 1. The evolution in Romania of the daily number of illnesses and deaths caused by the COVID-19 virus

Source: Health Minister of Romania (2020)

\section{LITERATURE REVIEW}

Even though much research has been carried out in the field of public procurement over the last three decades, one area that has been neglected is that of disaster / emergency public procurement and the role played by these procurement before and after disaster. However, disaster procurement is a key governmental activity for the economic recovery of the affected communities. Analysis of disaster procurement is very important because dangerous events (earthquakes, fires, floods, tsunamis, pandemics, terrorist attacks) increase the complexity and the constraints to which the procurement systems are subjected, highlighting the importance of transparency and effectiveness. Procurement systems that do not respond effectively during and after such disasters can have a long-term negative impact on the resilience and recovery of affected communities (Atkinson \& Sapat, 2012).In the US, the importance given to emergency procurement has increased since the terrorist attacks of 11 September 2001 (9/11) (Drabkin \& Thai, 2007). Emergency public procurement has been analyzed in the US at federal level, but coverage is very limited compared to its importance (Friar, 2006). Criss (2006) studied strategic supply in emergency situations, but did not focus on procurement procedures.Despite the lack of research in this area, emergency public procurement is a very important issue. Central or local public authorities have to deal with natural disasters (earthquakes, fires, floods, pandemics) and intervene quickly to limit the spread of disasters and their effects.This article carries out a literature research on emergency public procurement, analyzes the response of the Romanian public authorities to the crisis caused by the COVID-19 pandemic and seeks to identify a numder of gaps, advantages, disadvantages and risks of emergency procurement.

\section{RESEARCH QUESTIONS}

Through this research we try to answer the following questions:

1. What are the main problems of the Romanian public procurement as a result of the COVID-19 crisis?

2. What are the advantages and disadvantages of emergency public procurement? 
3. What are the main risks / vulnerabilities of these acquisitions?

4. What distinguishes emergency public procurement made following the COVID-19 pandemic from emergency procurement in the event of natural disasters (earthquakes, floods, fires, tsunamis)?

\section{EMERGENCY PUBLIC PROCUREMENT IN ROMANIA - A MEASURE TO COMBAT THE EFFECTS OF THE COVID-19 PANDEMIC}

In general, unforeseen circumstances (such as emergency situations) are very difficult scenarios to anticipate and manage. Even if the main considerations of regular procurement are the sale price and the possibility of delivery, in the case of urgent procurement the main constraint is the very short time needed to deliver the products or provide the services. In these situations, normal procurement procedures are bypassed and bidders are no longer required to meet criteria such as creating new jobs, supporting local firms or small and medium-sized enterprises (Newman, 2005). The prompt implementation and rigorous compliance of social distance measures and the fight against the virus are the only ways to maintain a low incidence peak and a mild evolution of the disease (Centrul pentru Inovație în Medicina și Raportul de Garda, 2020). Emergency procurement helps to increase the protection measures and the capacity of the medical system, it reduces the height of the evolution curve of the number of reported disease cases and moves up the horizontal line of the graph in Figure 2, meaning that it increases the treatment capacity of the public health system, which also leads to a reduction in the number of deaths.

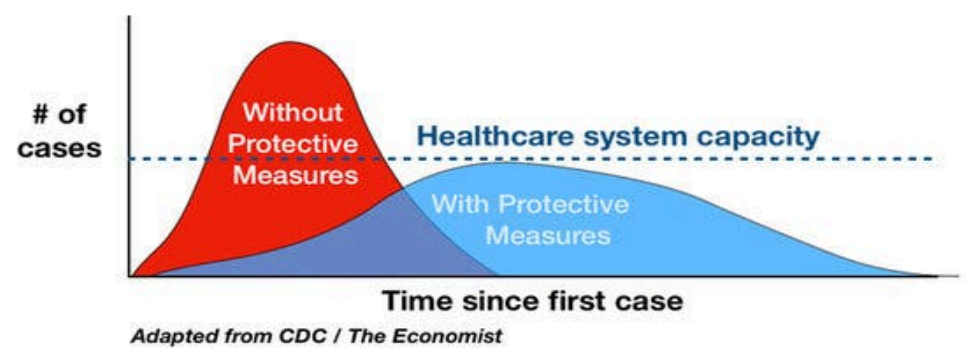

Figure 2. Simulation of the possible evolution of the COVID-19 epidemic Source: New York Times (2020)

The main factors influencing the spread of the epidemic are: the length of time from which a person is infected and can infect others, the measures of social distance (isolation, quarantine), the probable duration of the entire epidemic and the rate of infection expansion (Centrul pentru Inovatie în Medicina și Raportul de Garda, 2020). Emergency public procurement acts mainly on the last factor, namely the speed of virus expansion, which can be greatly reduced by purchasing ambulances, thermal scanners, disinfectants, masks and protective suits, etc.Also, one factor that has made emergency procurement more difficult and aggravated the effects of the crisis is the fact that China is the world's leading supplier of active pharmaceutical ingredients and key raw materials so that the Chinese blockade of production has affected global pharmaceutical production and thus global production costs. In the provinces of Hubei and Zhejiag in China alone, which were heavily affected by the virus, there are more than 100 production sites. Blockages and uncertainty 
have affected the delivery of medicines and medical supplies and have led to higher production costs and sales prices. Producers have encountered difficulties in meeting the delivery deadlines and thus some medicines and sanitary materials have either disappeared from pharmacies or become very expensive. For example, masks and protective costumes so necessary to combat a pandemic were mainly produced in China, which, due to the spread of the virus, has not been able to honor the orders (Mocanu, 2020). During the crisis, the Prime Minister of Romania urged that the speed of procurement should be increased and that purchases be made even when there is only one supplier, meaning without competitive procedures, since there were already shortages for the products concerned, import bans have emerged in some countries and in other countries medical products / materials / equipment have been requisitioned. The Romanian Minister of Public Finance also said that the Romanian National Office for Centralized Procurement (ONAC) was not designed for emergency procurement because it was conceived by previous governments (Năstase, 2020). Moreover, in Romania, until the outbreak of the epidemic, there was no public agency / authority that had the purpose / objectives / tasks of making emergency public procurement. ONAC was established by the Romanian Government Emergency Ordinance no. 46 / 31.05.2018, being the only institution in Romania that can procure on a centralised basis products such as: computers, cars, motor vehicle fuels, office supplies, furniture, medicines and pharmaceutical products. It was only in 2018 that this institution was established in Romania, since many other countries have central purchasing institutions established for a very long time: France (1968), USA (1949), Italy (1997) and Denmark (1994). During the pandemic, an Italian official said: "the pandemic is faster than the bureaucracy." This idea applies both to the situation in Romania and most of the affected countries. It was only on 04.02.20202, through the Emergency Ordinance of the Romanian Government no. 11 of 04.02.2020, ONAC was designated as a public institution empowered to organize and carry out medical emergency public procurement by using the negotiation procedure without prior publication, in accordance with the provisions of Law no. 98/2016 regarding public procurement. The negotiation procedure without prior publication is a non-competitive procedure that can be applied in cases of extreme urgency, but the contract concluded is valid only during the resolution of that emergency. In this procedure, the public authority conducts consultations with a single economic operator, which shall determine the selling price and the contract terms. The issue of non-competitive procedures in emergency situations is a widely debated issue in other countries as well. For example, in the US, following hurricanes Katrina and Wilma in 2005, there have been debates about the use of competitive versus non-competitive procedures in emergency procurement. The US Congress Supervisory Committees criticized FEMA (Federal Emergency Management Agency) for not using competitive procurement procedures, and FEMA argued through the short time available (Frisch, 2005). By the mentioned ordinance, together with ONAC (which was appointed to procure biocides), two other state authorities were appointed to carry out emergency procurement, namely the Romanian Department for Emergency Situations for the procurement of protective equipment (gloves, goggles, suits) and the Romanian Ministry of Transport for the procurement of thermoscanners. The funds were allocated in the amount of 225 million lei (approx. 46 million euros) from the Budget Reserve Fund available to the Romanian Government (Bechir, 2020). Despite the measures taken, the number of illnesses with COVID-19 continued to increase, so that on 16.03.2020, the President of Romania issued Decree no. 195 establishing the emergency state on Romanian territory. It should be mentioned that before the state of emergency decreed on 16.03.2020 following the coronavirus epidemic, the last time in Romania the state of emergency was instituted was in January 1999 when groups of miners attacked important Romanian state institutions. Therefore, the last two decrees of the state of emergency in Romania were made at an interval of 21 years. This very long time period creates great difficulties in training purchasers for such exceptional situations and worse, reduces the vigilance of public authorities. The establishment of the state of emergency has made it possible to allocate new resources for crisis management and made it possible to carry out procurement through simplified procedures. Thus, the Romanian 
National Agency for Public Procurement (ANAP) issued on 16.03.2020 a notification allowing contracting authorities to procure directly materials and equipment necessary to combat the COVID-19 epidemic. These authorities are the central public authorities, the entities in which the state is a majority shareholder, the public health departments, the health units and the ministries with their own health system. Emergency direct procurement are carried out by derogation from the provisions of Romanian Law no. 98/2016 regarding public procurement, that is even above the thresholds of 135,060 lei, excluding VAT (approx. 27,600 euros excluding VAT) for products and services and 450,200 lei, excluding VAT (approx. 92,000 euros excluding VAT) for works. Until the state of emergency was established, contracting authorities could only make direct procurement that did not exceed the two mentioned thresholds. Contracting authorities must verify compliance with the provisions of the Decree, draw up a note justifying the urgent need and the way in which the acquisitions contribute to combating the COVID-19 epidemic and carry out the actual direct procurement on the basis of the supporting documents necessary for the payment. Within a maximum of 30 working days after the end of the emergency period, all contracting authorities shall provide ANAP a statement containing the following information: the name of the contracting authority / entity, the economic operator from which the purchase was made, the invoice, the value of the procurement and the object of the procurement. Simplifying procurement procedures and increasing the value thresholds were measures taken in the areas affected by hurricane Katrina in the US in 2005. Thus, the value threshold for renting real estate was increased from USD 100,000 to USD 250,000, the threshold for micropurchases based on credit cards was increased from USD 2,500 to USD 7,500 and the threshold for simplified procedures was increased from USD 100,000 to USD 5,000,000. An exception was also made to the provisions of the BAA (Buy American Act) law, which regulates the preference for American products in the case of government procurement with a value higher than USD 175.000 , so the contractor's nationality was not taken into account (Drabkin \& Thai, 2007). The basic rules of public procurement must be simple and clear. della Porta and Vannucci (1999) claim that an excess of rules can suffocate the administrative system, further justifying emergency procedures that violate competition and transparency rules in emergency procurement procedures. It is important to clearly define the terms "immediately", "urgent" or "exceptional". Also, in order to reduce the threat of unforeseen circumstances, contracting authorities must request guarantees / assurances from the successful tenderers (della Porta \& Vannucci, 1999). According to the provisions of Romanian Law 98/2016, direct procurement is not considered to be an award procedure. The main advantages of direct procurement are the following: simplicity, short lead time, small number of documents to be drawn up, no appeals can be submitted by economic operators and contracting authorities can identify the necessary products / services from the electronic catalog of the Romanian Electronic Public Procurement System (SEAP). The most important disadvantages of the direct procurement are: the main criterion for differentiating the offers is the price (that is, it can only use the "lowest price" award criterion), no scores of the offers received are calculated, so quality cannot influence the score obtained (the products/services only have to meet minimum quality requirements) and the winning offerors do not guarantee proper performance, so contracting authorities are vulnerable to improper behavior of the economic operators. Thus, permission has been granted for any contracting authority to purchase protective materials: facial masks, protective gloves, protective clothing, surface and hands disinfectants (biocidal products). However, granting this permission has caused two major problems for contracting authorities with no experience in the health field, namely:

- establishment of technical specifications to ensure the procurement of quality products, since many inexperienced economic operators have started to produce such materials in order to take advantage of the opportunities of this crisis;

- verification that these technical specifications are met upon receipt of purchased products so that non-compliant products (counterfeit or substandard) can be rejected. 
The first problem could be solved either by requesting specifications from the authorities that previously carried out such procurement or, more seriously, by receiving these specifications even from the economic operators who were selling those products (meaning that the needs of the contracting authority have not been fully taken into account). But the second problem has remained unresolved for most contracting authorities because at the national level there are only a few institutions that can determine whether or not a sanitary material meets the standards in force. Under the emergency conditions, it has become practically impossible to check each batch of medical products delivered. This could be an important reason why centralization (in the case of regular procurement) can be required because a central authority with specialists in the field is more difficult to deceive. It should be mentioned that in 2016 in Romania there was a big public scandal about a company that produced biocides that did not comply with the current standards (the disinfectants were diluted). These biocides were marketed without being properly verified by the competent Romanian state institutions, the irregularities being detected following a press investigation. In this case the court ordered the company to be dissolved and sentenced the company to pay a criminal fine of 2.6 million lei (approx. 540,000 euros) for cheating over 300 hospitals in Romania to which the firm sold diluted disinfectants. The company's director was sentenced to 3 years in prison, the production director was sentenced to 3.8 years in prison and the former owner committed suicide shortly after the investigation began (Stoica, 2019). Unfortunately, since the years before the COVID-19 crisis broke out, this case has shown that the Romanian public authorities have not been able to prevent the sale of products that have endangered public health. However, there are European states where the stocks of medical products supplied are carefully checked at all times, even during the COVID-19 crisis. An example of this is the Netherlands, which, during the crisis, withdrew 600,000 FFP2 facial masks from a lot of 1,3 million imported from China, because they did not meet the quality standards. These masks had defects, meaning that they did not close correctly on the face or their membranes were not functioning correctly. In this context, OLAF (European Anti-Fraud Office) has opened an investigation into the import of counterfeit health products in Europe in the context of the COVID-19 crisis (Lupitu, 2020). Measures have also been taken at European level to combat the COVID-19 pandemic through centralized joint procurement procedures. On 28.02.2020 and 17.03.2020 respectively, two joint procurement procedures were initiated for the purchase of type 2 and 3 protective masks, respectively protective goggles, protective visors and protective suits. 25 Member States participated in these joint procurement, under the coordination of the European Commission. These procurement procedures were successful because the producers who participated in these procedures offered quantities covering or even exceeding the quantities requested by the Member States. The joint procedures took about one week and the delivery deadline for these sanitary materials was two weeks (European Commission, 2020a). The agencies that carry out centralized procurement buy only certain types of products for other beneficiary institutions at lower purchase prices but in larger quantities. Thus aggregate demand must also be homogeneous (Lukic et al., 2015).

The main advantages of centralized procurement are: lower purchase prices (increased efficiency), standardization of purchased products, achieving economies of scale by producers, increased bargaining power of the central procurement agency, reduction of the number of documents to be prepared and reduction of storage, handling and transport costs. The most important disadvantages of centralized procurement are: reduced flexibility (reduced capacity to adapt to unique needs), reduced participation of small and medium-sized enterprises, the occurrence of anti-competitive agreements, increased processing time of orders, reduced competences of the purchasers from beneficiary institutions, blocking centralized procurement procedures by submitting appeals and 
development of corruption (Dimitri et al., 2006; Thai et al., 2009). Wilkinson (2007) examined public procurement in the event of disasters in the United States and concluded that the US Federal Government failed to plan emergency procurement, because when they occurred, it did not provide a rapid response consisting of quality products at reasonable prices. Unfortunately, this also applies to Romania. The Romanian Government, through the Romanian National Administration of State Reserves and Special Problems (ANRSPS) has constituted emergency stocks of water, nonperishable food, fuels, tents, building materials that are suitable for natural disasters such as earthquakes, floods, fires, but has not constituted stocks of materials and equipment needed to fight the effects of pandemics (masks, protective suits, disinfectants, respiratory devices). Federal agencies in the US that conducted emergency procurement have faced a number of problems, such as the lack of adequate measures to speed up emergency services, the lack of human resources, unclear agency objectives, government officials lacking the skills and qualifications needed to manage crises (Schneider, 2005). Another vulnerability observed by Bumiller (2005) in USA was the replacement of experienced civil servants with political novices in some government agencies, which reduced the capacity to manage crisis situations. Unfortunately, this also applies to Romania where many directors of government agencies or hospital directors have been appointed on political criteria and not on the basis of competence and experience in the field. One of the neglected issues of ordinary procurement, but especially in the case of emergency procurement, is the strategic function that procurement has to implement government policies (NASPO, 1997; O'Brien, 2011). Quak et al. (2019) stressed that public procurement is a strategic tool used to achieve political objectives.

\section{THE RAPIDITY - MAIN ADVANTAGE OF EMERGENCY PUBLIC PROCUREMENT}

The rapidity is the most important feature of emergency procurement. The objective of purchasing quickly the necessary products and services in an emergency and above all, at reasonable prices, while maintaining transparency and providing opportunities for local businesses is very difficult to achieve in practice (Atkinson \& Sapat, 2012).

Table 1 shows the average duration of the procurement procedures conducted in Romania between 2016 and 2018.

Table 1. The average duration of the procurement procedures conducted in Romania between 2016 and 2018

\begin{tabular}{|c|c|c|c|c|c|c|c|}
\hline \multirow{2}{*}{ No. } & Year & \multicolumn{2}{|c|}{$\begin{array}{c}\text { Average duration of procedures not verified } \\
\text { ex-ante by ANAP (days) }\end{array}$} & \multicolumn{2}{|c|}{$\begin{array}{c}\text { Average duration of procedures verified } \\
\text { ex-ante by ANAP (days) }\end{array}$} \\
\cline { 2 - 8 } & $\begin{array}{c}\text { Preparation } \\
\text { of the } \\
\text { procedure }\end{array}$ & $\begin{array}{c}\text { Carrying } \\
\text { out the } \\
\text { procedure }\end{array}$ & $\begin{array}{c}\text { The average } \\
\text { duration of } \\
\text { the award } \\
\text { process }\end{array}$ & $\begin{array}{c}\text { Preparation } \\
\text { of the } \\
\text { procedure }\end{array}$ & $\begin{array}{c}\text { Carrying } \\
\text { out the } \\
\text { procedure }\end{array}$ & $\begin{array}{c}\text { The average } \\
\text { duration of } \\
\text { the award } \\
\text { process }\end{array}$ \\
\hline 1 & 2016 & 13 & 69 & $\mathbf{8 2}$ & 17 & 75 & 92 \\
\hline 2 & 2017 & 14 & 77 & $\mathbf{9 1}$ & 25 & 89 & 114 \\
\hline 3 & 2018 & 13 & 82 & $\mathbf{9 5}$ & 31 & 112 & 143 \\
\hline
\end{tabular}

Sources: (ANAP, 2017; ANAP, 2018; ANAP, 2019)

As can be seen, the average duration of the procurement procedures carried out in Romania in 2018 was 95 days, in the case of the procedures that were not verified ex-ante by ANAP, respectively 143 days, in the case of the procedures that were verified ex - ante by ANAP. It is quite clear that in the case of a global pandemic, where every hour counts and the lives of people / patients depends on 
how quickly the necessary measures are implemented, normal procurement procedures cannot be applied and simplified procurement procedures need to be applied as quickly as possible. The speed of the implementation of anti-pandemic measures is essential especially in the context of other measures following the establishment of the state of emergency, such as: the prohibition of traffic on public roads, the prohibition of road, rail, air, maritime, river transport with some states and the closure of state borders. These measures have led to blockages in the supply of various medical products / equipment, which has made the procurement even more difficult.Emergency procurement made to combat the COVID-19 pandemic are distinguished from emergency procurement in the event of natural disasters through the much more difficult conditions under which they are carried out. Unlike other local emergencies, the COVID-19 pandemic is global in nature, which has led to an explosion of demand and implicitly to shortages of health materials and medical equipment, increased production costs and sales prices, blockages in the supply chain, requisition of sanitary materials in some states, the closure of state borders, the ban of transport and the blockage of Chinese medical production that has affected the global pharmaceutical industry. Hanak and Muchova (2015) consider that the efficiency of spending public funds is the most important issue in the case of ordinary procurement which is influenced by the level of competition. As regards the level of competition, Thai et al. (2009) consider that in order to obtain an adequate market response and to spend the funds efficiently, at least four firms need to participate in a procurement procedure. The situation is becoming less and less favorable to public authorities as fewer offers are received (three or two) and if only one offer is received the situation is catastrophic (Thai et al., 2009). In the case of procurement made following a global epidemic (pandemic), it is practically impossible to maintain an acceptable level of competition. The efficiency of the use of funds is very low, especially in the case of medical supplies and equipment for which there is an explosion in global demand. The lack of emergency stocks / reserves, the reduced production capacity of such materials / equipment at national level, closure of borders, requisitions made in other states, make it difficult or even impossible to carry out the procurement procedures and deliver the necessary products. The reduced production capacity at national level is due to the low competitiveness of Romanian firms in the context of the increasing exposure of the national economy to globalized markets. However, any crisis presents opportunities. Due to the very high demand for sanitary materials and equipment, many Romanian economic operators have tried to take advantage of the new business opportunities created by the spread of the pandemic. Some companies purchased new production lines, others changed/adapted existing ones and started manufacturing various sanitary materials. The acquisition and change of the production lines was also done by implementing some governmental measures that consisted in granting loans guaranteed by the Romanian state. For example, Romanian military researchers have designed an isolated stretcher for the transportation of infected persons (which immediately went into production), a company that usually manufactures flags started to manufacture protective masks, another company that produced cosmetics started to manufacture biocides and a chemical plant that manufactures chlorine-based products started to manufacture disinfectants. A Romanian biocides factory that had been closed several years before the crisis because the disinfectants did not meet the standards in force, following the state decree of emergency, was requisitioned by the Romanian state and started producing biocides according to standards (Pricop, 2020).

\section{CORRUPTION - THE MOST IMPORTANT RISK OF EMERGENCY PUBLIC PROCUREMENT}

The main risks of emergency procurement are:

- the intervention of political factors in purchasing decision making; 
- improper identification of the needs which may result in incorrect or incomplete establishment of technical specifications, estimated values, quantities required. Buying more can lead to unnecessary stocks and affect the institutions / people who need those resources;

- making unjustified purchases due to the emergency situation (falsified or invented needs);

- insufficient competition;

- reduced transparency;

- acceptance of technical specifications of the products offered which do not meet the standards in force;

- lack of monitoring of the fulfillment of the contractual obligations by winning offerors;

- failure to establish/provide a guarantee of proper performance of the contract;

- the absence of institutions specialized in emergency public procurement;

- lack of clear procurement procedures to be applied only in emergency situations;

- lack of specialized personnel (competent and experienced procurers);

- development of the phenomenon of corruption.

Corruption is defined as "the abuse of power for private gain" (EC - European Commission, 2014; TI - Transparency International, 2015).

Corruption in emergency public procurement reduces the resources available for rescue operations, reduces the quality of the products and services provided, and diverts aid from those most in need. In the case of humanitarian aid, corruption has a negative impact on the support of the public and non-governmental organizations both in the affected country and abroad (Schultz \& Soreide, 2008). Emergency procurement is far more risky than regular procurement, as public authorities are more reluctant to take risks compared to private firms (Georghiou et al., 2013). Irimia-Dieguez et al. (2014) consider that the risk of fraud increases in non-competitive procedures that are less transparent and in situations of force majeure (natural disasters, wars, terrorism acts).Emergency public procurement is more vulnerable to corruption due to its urgency, product shortages and high market prices. Schultz and Søreide (2008) consider that "rushed" procurement, with high funding, reduced controls and frequent staff changes are a "recipe" for corruption and fraud.In the procurement of medical products / materials / equipment, bribes can also be accepted for incomplete deliveries, low-quality, expired or even counterfeit medicines / sanitary materials (Schultz \& Soreide, 2008). In an emergency situation such as the COVID-19 pandemic, the procurement of substandard, expired or counterfeit sanitary materials can have catastrophic consequences: masks and protective suits no longer protect the medical personnel and the people who wear them, disinfectants no longer destroy viruses, leading to spread of the pandemic and affecting the medical personnel and the population. It should be noted that medical staff is the most important and vulnerable resource in the fight against a pandemic. The speed with which procurement must be made in emergency situations can be a motivation for the exemption from existing regulations in order to commit corruption acts. After an earthquake / tsunami or environmental disaster some government agencies may be empowered to make purchases except for normal procurement procedures or monitoring procedures. The agencies in question are thus given a great discretionary power that favors corruption and makes it less risky (Soreide, 2002).The main consequences of the corruption phenomenon are the increase of costs / prices, the reduction in quality, the damage of people's health and the decrease in confidence in the government and public institutions (TIR, 2014). In emergency situations, rising prices as a result of corruption make essential financial resources wasted and products even more inaccessible to patients in need. The loss of confidence in public institutions managing the crisis can lead to negative effects such as lines at grocery stores, lack of food products or the resignation of health professionals (doctors, nurses).Procurement procedures under emergency conditions are often less transparent. Kenny (2012) emphasized the importance of transparency of procurement procedures in the fight against corruption while Tabish and Jha (2012) concluded that there was an inverse relationship between 
corruption and transparency indicators, compliance with procedures and contractual clauses.In a context where public procurement is an important point of contact between public administration and the economy, Kirn et al. (2019) stressed that budget funds allocated to public procurement are a source of corruption and conflicts of interest.According to a study carried out by the World Bank in 2012, out of a total of 215 countries analyzed, Romania ranked last in terms of control over the phenomenon of corruption and governance efficiency (LP, 2017).In the case of ordinary procurement, as a result of corruption acts, the costs can increase by $20-25 \%$ or even $50 \%$ (TIR, 2014; Evenett \& Hoekman, 2005). In the case of emergency procurement, these percentages may be much higher, which is an important incentive for corruption. An indicator of the level of corruption in the public sector is the CPI - corruption perception index, used in more than 180 countries (Transparency International, 2014). This quantitative indicator characterizes the degree of bribe acceptance by civil servants and politicians in each country analyzed (Rahman et al., 2015). Figure 3 shows the dynamics of this indicator between 2009 and 2018 in the case of Romania. In the period 2015-2018 the indicator had values between 46 and 48 ( 0 being high level of corruption and 100 being low level of corruption) (Transparency International, 2018).

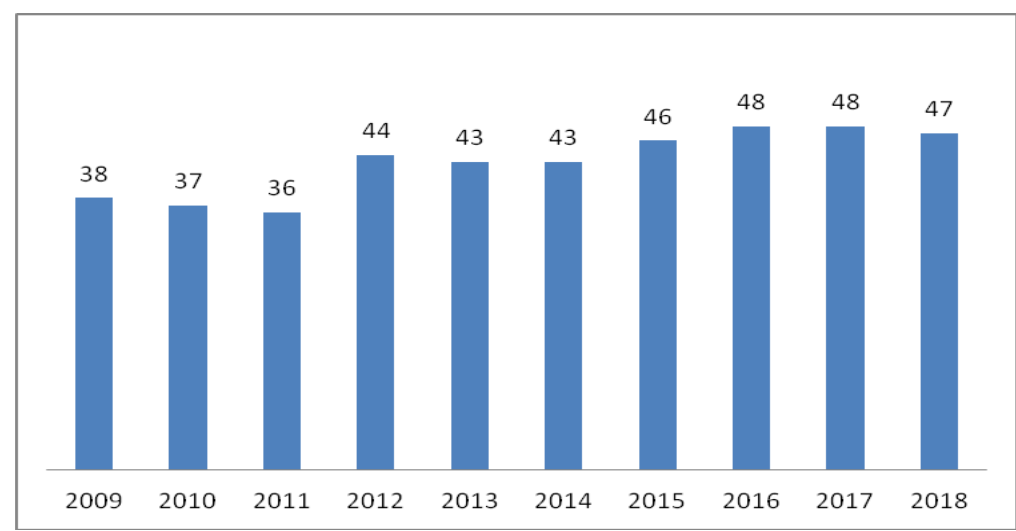

Figure 3. The dynamics of the CPI index between 2009 and 2018 in the case of Romania Source: Trading Economics (2019)

Schultz and Soreide (2008) have identified the main factors that favor opportunities for corruption in emergency procurement. According to the mentioned authors, these are: the size and location of the contract, the complexity of the products / services needed, the confidentiality of identifying the needs of the beneficiaries, the reduced controls, the increased demand, the pressure to spend the funds allocated as soon as possible, the geographical location of the affected area, the experience of public authorities in managing emergency situations and the country of origin of economic operators offering products and services. Le Billon (2005) mentioned that procurement carried out in emergency situations lead to market distortion and may have long-term consequences. Under these circumstances, the bargaining power of the state authorities is greatly reduced and the firms that pay bribes to obtain contracts recover their money by unduly increasing their purchase prices. This also means greater profits for these firms which can then be used to increase market power by other legal means / mechanisms such as extended advertising or aggressive price reductions (Le Billon, 2005). Unfortunately, in the case of Romania, corruption is a major problem. At the moment of this research, a former health minister in Romania was arrested for 30 days, being accused of taking bribes in case of the award of a contract aimed at designing and arranging an operating room and adjacent premises in a hospital. Investigators accuse the former minister that the bribe was taken in two tranches worth 10,000 euros, respectively 24,000 euros, representing a total of about $7 \%$ of the contract value. The former health minister was caught in flagrant when he received the second tranche of the bribe (Zamfirescu, 2020). The measures to prevent corruption in emergency procurement are: (1) the organization in advance of procurement for frequently used products and 
services at pre-determined prices. Procedures can be carried out and framework agreements concluded in advance in which the maximum quantities cover the needs arising from certain emergency situations; (2) purchase of standard products; (3) risk analysis and assessment; (4) record keeping of suppliers; (5) implementation of human resources policies adapted to the emergency situations; (6) strengthen professional integrity by administrative codes that sanction corruption. Bribery firms should no longer be able to participate in procurement procedures for a period of time; (7) establishment and development of public administration structures to manage emergency situations; (8) coordination of central procurement (centralized procurement) with local procurement (decentralized); (9) involvement of experienced procurers and (10) collaboration between procurers from different public authorities, exchange of information about suppliers (Schultz \& Soreide, 2008).The financial resources to be managed in emergencies are very large. At European level, the European Commission has proposed a budget of 37 billion euros to deal with the COVID-19 crisis, with over 1 billion euros being allocated to Romania. EU Member States were also able to allocate additional funds in the fight against the pandemic and could exceed the maximum deficit accepted at european level of 3\% of GDP. One of the measures taken at European level has been to ensure the necessary supplies to the national health systems by preserving the integrity of the single market, the production and distribution of medical protection equipment and medicines (European Commission, 2020b). Another example of the size of the resources allocated is the Indian Ocean tsunami that took place on December 26, 2004. This was followed by a "second tsunami" of aid and donations to help and rebuild the affected countries, which totaled USD 13,5 billion (TEC, 2006). However, procuring goods and services as a matter of urgency is a very vulnerable process. For example, in Indonesia, evaluation teams found that a common practice was to provide "incentives" for concluding contracts of around $10 \%$. If $30 \%$ of the total funds were earmarked for public procurement, then the potential losses were very large (approx. USD 405 million) (International Group for Anti-Corruption Coordination, 2005).In Romania, some firms have used the COVID-19 crisis to increase prices unjustifiably. For example, before the crisis 0.5 liters of sanitary alcohol costs 4 lei and during the crisis it costs 20-25 lei, and before the crisis a surgical mask costs 0.3 lei and during the crisis it costs 6-9 lei (meaning increases of prices between $600 \%$ and 3,000\%) (Burlă, 2020).Under these circumstances, the Romanian Competition Council has followed the conduct of the companies so that they do not: increase prices without objective justification, exchange information (about commercial policy or prices), exclude competitors from the market, abuse the dominant position and make anti-competitive agreements (Zamfir, 2020).

\section{CONCLUSIONS}

Emergency public procurement contributes to the implementation of protective measures and to increasing the capacity of the medical system to cope with the COVID-19 pandemic. Reducing the rate of virus spread is achieved through the emergency procurement of medical materials and equipment. The main feature of emergency public procurement is the speed with which products and services must be purchased. In these circumstances, ensuring proper competition and efficiency in the use of public funds is becoming very difficult to achieve.In the case of Romania, the research found that the public authorities were not prepared to combat such a crisis: there were no stocks of medical supplies, until the crisis started, there was no government agency aimed at making emergency procurement and the capacity to produce sanitary materials at national level was very low, which made Romania largely dependent on the import of such materials. Contracting authorities in Romania that carried out emergency procurement of medical materials / equipment have faced a number of problems such as the establishment of technical specifications, the verification of compliance with these technical specifications at the reception of products and there were not enough agencies at national level to control the quality of the materials procured. Other problems faced by public authorities were the explosive increase in demand for medical supplies, 
rising prices, bottlenecks in supply, border closures, transportation difficulties and blocking Chinese pharmaceutical production. The research also found that emergency public procurement is more vulnerable to corruption due to its urgency, higher prices and product shortages. Before the COVID-19 crisis, there were cases of high-level corruption in the Romanian health system. Many companies in Romania have tried to take advantage of new opportunities arising from the explosion of the demand for medical supplies and have started to produce protective equipment (masks, suits, glasses) and disinfectants (biocides).Future research could analyze the possible correlations between the implemented measures to combat virus spread (quarantine, city blocking, opening new hospitals, emergency procurement) and their effects (reduction in the number of illnesses, deaths) to determine the effectiveness of these measures.Also, future research could analyze the problems regarding emergency public procurement in countries other than Romania in the case of the COVID-19 pandemic, other pandemics or natural disasters (floods, earthquakes, fires, tsunamis). The continuous improvement of emergency procurement methods / procedures can help increase the efficiency of the use of funds, reduce corruption, reduce the recovery time of affected communities and save lives that are priceless and irreplaceable.

\section{REFERENCES}

Alecsandru, I. (2020). Primul român vindecat de coronavirus a spus adevărul. Ce i-au făcut medicii, Retrieved March 22, 2020, from https://www.capital.ro/primul-roman-vindecat-decoronavirus-a-spus-adevarul-ce-i-au-facut-medicii.html

ANAP. (2015). Strategia națională în domeniul achizițiilor publice. Retrieved December 9, 2019, from http://anap.gov.ro/web/strategia-nationala-in-domeniul-achizitiilor-publice/

ANAP. (2017). Raport statistic 01 ianuarie - 31 decembrie 2017 privind procedurile de atribuire a contractelor de achiziție publică/sectoriale inițiate în cadrul SEAP prin publicare de anunț de participare/anunț de participare simplificat/invitație de participare. Retrieved August 26, 2019, from http://anap.gov.ro/web/wp-content/uploads/2018/02/Situatie-APIP-an-2017.pdf

ANAP. (2018). Raport statistic 01 ianuarie - 30 iunie 2018 privind procedurile de atribuire a contractelor de achiziție publică/sectoriale inițiate în cadrul SEAP/SICAP prin publicare de anunț de participare/anunț de participare simplificat/invitație de participare. Retrieved August 27, 2019, from http://anap.gov.ro/web/wp-content/uploads/2019/01/RAPORTSTATISTIC-APIPAPS-Semestrul-II-2018.pdf

ANAP. (2019). Indicatorii de monitorizare a eficienței procedurilor de achiziție publică finalizate prin contract în anul 2018. Retrieved December 2, 2019, from http://anap.gov.ro/web/wpcontent/uploads/2019/09/Indicatori-de-monitorizare-2018_final-23Sep2019.pdf

Atkinson C. L., Sapat. \& A. K. (2012). After Katrina: comparisons of post-disaster public procurement approaches and outcomes in the New Orleans area. Journal of Public Procurement, 12 (3), 356-385.

Bechir, M. (2020). Cum face România tranșee în fața Covid-19: Echipamentele sunt de la criza de Ebola, stocurile de rezervă sunt zero, miercuri încep achizițiile în regim de urgență, Retrieved March 19, 2020, from https://cursdeguvernare.ro/cum-face-romania-transee-infata-covid19-echipamentele-sunt-de-la-criza-de-ebola-stocurile-de-rezerva-sunt-zeromiercuri-incep-achizitiile-in-regim-de-urgenta-importuri-din-america-de-sud.html

Bumiller, E. (2005). Democrats and Others Criticize White House's Response to Disaster', New York Times, cited in Drabkin D. \& Thai, K. V., (2007). Emergency contracting in the US federal goverment. Journal of Public Procurement, 7(1), 84-103.

Burlă, V. (2020)._Speculă cu spirt și de ce măștile chirurgicale costă pe internet de 30 ori prețul lor. Retrieved March 23, 2020, from https://romania.europalibera.org/a/spirtulm\%C4\%83\%C8\%99tile-chirurgicale-vand-30-mai-scump/30490409.html 
Centrul pentru Inovație în Medicină și Raportul de Gardă (2020). PREDICȚIE. 3 scenarii posibile pentru VÂRFUL epidemiei. Cum ar putea evolua \#COVID19 în România? Retrieved March 20, 2020, from https://raportuldegarda.ro/articol/predictie-scenarii-varf-covid19-evolutieromania/

Criss, R. M. (2006). Strategic Sourcing in an Emergency Contracting Environment. Contract Management, 46 (1), 12-24.

Cremer, G. (2000). On the Problem of Misuse in Emergency Aid, cited in Schultz J., Soreide, T. (2008). Corruption in Emergency Procurement. Disasters, 32 (4), 516-536.

Della Porta, D. \& Vannucci, A. (1999). Corrupt exchanges: Actors, resources and mechanisms of political corruption. Aldine de Grutyer, New York, cited in Soreide T. (2002). Corruption in public procurement. Causes, consequences and cures, Chr. Michelsen Institute - Development Studies and Human Rights, Retrieved March 20, 2020, from https://www.cmi.no/publications/file/843-corruption-in-public-procurement-causes.pdf

Dimitri, N., Piga, G. \& Spagnolo, G. (2006). Handbook of procurement. Cambridge, UK: Cambridge University Press.

Drabkin, D. \& Thai, K. V. (2007). Emergency contracting in the US federal goverment. Journal of Public Procurement, 7(1), 84-103.

European Commission. (2014). Businesses' attitudes towards corruption in the EU. Brussels.

European Commission. (2017). Semestrul european - Fișă tematică: Achizițiile publice. Brussels.

European Commission. (2020a). Coronavirus: Procedura de achiziții lansată de Comisie pentru a asigura aprovizionarea cu echipamente individuale de protecție pentru Uniunea Europeană a avut succes. Brussels.

European Commission. (2020b). UE împotriva COVID-19. Brussels.

European Council. (2020). Răspunsul Consiliului la crize (IPCR) - Epidemia de coronavirus Covid-19. Brussels.

Evenett, S. J. \& Hoekman, B. M. (2005). Government procurement: Market access, transparency, and multilateral trade rules. European Journal of Political Economy, 21(1), 163-183.

Friar, A. (2006). Federal Contracting in Emergencies: A Critical Skill. Contract Management, 46(3), 22-24.

Frisch, K. K. (2005). Spotlight Focuses on Federal Procurement: Federal Emergency Management Agency's Competitive Contracting Strategy. Government Procurement, 13(5), 1-14.

Georghiou, L., Edler, J., Uyarra, E. \& Yeow, J. (2013). Policy instruments for public procurement of innovation: Choice, design and assesment. Technological Forecasting \& Social Change, 86(2014), 1-12.

Hanak, T. \& Muchova, P. (2015). Impact of competition on prices in public sector procurement. Procedia Computer Science, 64(2015), 729-735.

Health Minister of Romania. (2020). Communicate de presă._Retrieved April 6, 2020, from http://www.ms.ro/comunicate/

International Group for Anti-Corruption Coordination. (2005). Report on the Seventh Meeting of the International Group for Anti-Corruption Coordination, cited in Schultz J. \& Soreide, T. (2008). Corruption in Emergency Procurement. Disasters, 32 (4), 516-536.

Irimia-Dieguez, A., I., Sanchez-Cazorla, A. \& Alfalla-Luque, R. (2014). Risk Management in Megaprojects. Procedia - Social and Behavioral Sciences, 119(2014), 407 - 416.

Kenny, C. (2012). Publishing Construction Contracts to Improve Efficiency and Governance. Proceedings of the ICE - Civil Engineering, 165(5), 18-22.

Kirn, M., Umek, L. \& Rakar, I, (2019). Transparency in public procurement - The case of Slovenia. Danube: Law, Economics and Social Issues Review, 10(3), 221-239.

Le Billion, P. (2005). Buying Peace or Fuelling War: The Role of Corruption in Armed Conflicts. Journal of International Development, 15 4), 413-426. 
Lukic, I., Belic, I. \& Vlaovic, D. (2015). Consolidated (Central) Public Procurement as Effective Tool for the County Management for Rationalization of Costs of Regional Units. Interdisciplinary Management Research, 11, 491-505.

Lupitu, R. (2020). Coronavirus: Olanda a retras 600.000 de măști defecte importate din China. Retrieved March 31, 2020, from https://www.caleaeuropeana.ro/coronavirus-olanda-a-retras600-000-de-masti-defecte-importate-din-china/

Man, P., Matejkova, J., Jurcik, R. \& Heidu, R. (2014). The key factors of transparency of the public procurement in the Czech Republic. Procedia Economics and Finance 12(2014), 379386.

Mocanu, S. (2020). Impactul Covid-19 asupra fabricării medicamentelor și a consumabilelor în Europa: pericol în România doar dacă criza se prelungește după 15 martie, Retrieved March 21, 2019,

from https://360medical.ro/stiri/impactul-covid-19-asupra-fabricarii-medicamentelor-si-aconsumabilelor-in-europa-pericol-in-romania-doar-daca-criza-se-prelungeste-dupa-15martie/2020/02/19/

NASPO (1997). State and Local Government Purchasing: Principles \& Practices cited in Thai, K., V. et al. (2009), International Handbook of Public Procurement, Boca Raton, Florida, Ed. Taylor \& Francis Group, p. 93.

NASPO (1999). State procurement: Strategic positioning for the 21st century, cited in Coggburn, J. D. (2003). Exploring differences in the American States' procurement practices, Journal of Public Procurement 3 (1), 3-28.

Năstase, A. (2020). Ludovic Orban, către ministrul Florin Cîtu: 'Aştept de la ONAC un comportament mult mai participativ şi cooperant', Retrieved March 12, 2020, from https://www.stiripesurse.ro/ludovic-orban-catre-ministrul-florin-citu-astept-de-la-onac-uncomportament-mult-mai-participativ_1439036.html

Newman, D. (2005). Procurement's Role in an Emergency or Disaster, cited in Atkinson C. L. \& Sapat, A. K. (2012). After Katrina: comparisons of post-disaster public procurement approaches and outcomes in the New Orleans area. Journal of Public Procurement, 12 (3), 356-385.

New York Times (2020). Flattening the Coronavirus Curve, Retrieved March 19, 2020, from https://www.nytimes.com/2020/03/11/science/coronavirus-curve-mitigation-infection.html

O'Brien, J. (2011). Category Management in Purchasing: A Strategic Approach to Maximize Business Profitability, eds 2-a. New York, NY: Prentice Hall.

Pricop, S. (2020),_România a început producția de măști sanitare. Urmează dezinfectanții. Ce companii se reconvertesc?.

Retrieved March 21, 2020, from https://romania.europalibera.org/a/program-masti-sanitarefonduri-de-la-stat/30495391.html

Rahman, I. K. A., Rahman, N. A. A., Azhar, Z., Omar, N. \& Said, J. (2015). Management Accounting Best Practices Award for Improving Corruption in Public Sector Agencies. Procedia Economics and Finance, 31 (2015), 503-509.

Quak, H., Nesterova, N. \& Kok, R. (2019). Public procurement as driver for more sustainable urban freight transport. Transportation Research Procedia, 39, 428-439.

Schultz, J. \& Soreide, T. (2008). Corruption in Emergency Procurement. Disasters, 32 (4), 516536.

Schneider, S. K. (2005). Administrative Breakdowns in the Governmental Response to Hurricane Katrina. Public Administration Review, 65 (5), 515-516

Soreide, T. (2002). Corruption in public procurement: causes, consequences and cures. Retrieved June 21, 2019, from https://open.cmi.no/cmixmlui/bitstream/handle/11250/2435744/R\%202002-1.pdf?sequence=2\&isAllowed=y 
Stoica, I. (2019). Amendă uriașă pentru Hexi Pharma, care va fi dizolvată. Directorul companiei, 3 ani de închisoare cu executare. Retrieved April 4, 2020, from https://ziare.com/hexipharma/flori-dinu/amenda-uriasa-pentru-hexi-pharma-care-va-fi-dizolvata-directorulcompaniei-3-ani-de-inchisoare-cu-executare-1547753

Tabish S., Z. N. \& Jha K., N. (2012). The impact of anti-corruption strategies on corruption free performance in public construction projects. Construction Management and Economics, 30 (1), 21-35.

TEC - Tsunami Evaluation Coalition (2006). Joint Evaluation of the International Response to the Indian Ocean Tsunami: Synthesis Report. Retrieved October 2, 2018, from https://www.sida.se/contentassets/f3e0fbc0f97c461c92a60f850a35dadb/joint-evaluation-ofthe-international-response-to-the-indian-ocean-tsunami_3141.pdf

Thai, K., V. et al. (2009), International Handbook of Public Procurement. Boca Raton, Florida: Ed. Taylor \& Francis Group.

Trading Economics. (2019). Romania Corruption Index. Retrieved August 25, 2019, from https://tradingeconomics.com/romania/corruption-index.

Transparency International. (2014). Corruption perceptions index 2014: results. Retrieved August 25, 2019, from https://www.transparency.org/cpi2014/results.

Transparency International. (2018). Corruption Perceptions Index 2018: Romania. Retrieved August 26, 2019, from https://www.transparency.org/country/ROU

TIR - Transparency International Romania. (2014). Riscuri de corupție în achizițiile publice Excelență și integritate în achizițiile publice._Retrieved July 3, 2019, from https://www.transparency.org.ro/proiecte/proiecte_incheiate/2010/proiect_3/Riscuri\%20de\%2 0coruptie\%20in\%20achizitii\%20publice.pdf

Transparency International. (2015). FAQS on corruption, cited in Locatelli, G., Mariani, G., Sainati, T. \& Greco, M. (2016). Corruption in public projects and megaprojects: There is an elephant in the room!. International Journal of Project Management, 35 (2017), 252-268.

Wilkinson, K. J. (2007). More Effective Federal Procurement Response to Disasters: Maximizing the Extraordinary Flexibilities of IDIQ Contracting. Air Force Law Review, 59, 231-286.

Zamfir, C. (2020). Consiliul Concurenței urmărește firmele, să nu crească nejustificat prețurile, folosindu-se de criza coronavirus COVID-19. Retrieved March 22, 2020, from https://economie.hotnews.ro/stiri-consumator-23722086-consiliul-concurentei-urmarestefirmele-nu-creasca-nejustificat-preturile-folosindu-criza-coronavirus-covid-19.htm

Zamfirescu, G. (2020). Este bomba serii! Sorina Pintea a fost arestată preventiv: Acuzații extrem de grave. Retrieved March 21, 2020, from https://www.capital.ro/este-bomba-serii-sorinapintea-a-fost-arestata-preventiv-acuzatii-extrem-de-grave.html 